\title{
Pengaruh Ukuran Perusahaan, Likuiditas, Leverage, dan Margin Laba Kotor terhadap Pemilihan Metode Penilaian Persediaan
}

\author{
Akuntansi \\ Winda Meilia ${ }^{*}$, Dien Noviany Rahmatika ${ }^{2}$ \\ ${ }^{1,2}$ Fakultas Ekonomi dan Bisnis, Universitas Pancasakti Tegal \\ *Email: windameilia12@gmail.com
}

\section{ABSTRACT}

This study aimssto detrmine the Effectt of Company Size, Liquidty, Leverage And Profit Margin Against Selection Inventory Valuation Method (Case Study in the food and baverage company listd on the Indonesia Stock Exchage year 2016-2018). The population of this study is a food and beverage company listed on the Indonesia Stock Exchange in the 2015-2018 period. The research sample consisted of 36 companies. The sampling technique with purposive sampling technique. The datas used is secondary data on annual reports of food and beverage companies listed on the Indonesiia Stock Exchange. This research uses logistic analysis method with SPSS program. The results showed that company size effects on the selection of inventorys valuation methods with a significant value of 0,023. Liquidity does not affect the selection of inventory valuations methods with a significant value of 0,449. Leverage does not affect the selection oof inventory valuation methods with a significant value of 0,926. And the gross profit margin effects on the selction of iinventory valuation methods with a significant value of 0,027.

Keywords: company size, liquidity, leverage, gross profit margin, inventory method.

\section{PENDAHULUAN}

Perkembangan dunia usaha yang pasat telah membawa pengaruh besar dalam perkembangan dunia ekonomi di Indonesia. Hal tersebut terlihat dengan adaya persaingan yang ketat dalam dunia usaha dan adanya tuntutan konsumen akan produk dan jasa yang dikonsumsinya. Adanya persaingan yang ketat mengharuskan perusahaan untuk mengelola sumber daya secara efisien dan efektif agar perusahaan dapat tetap bertahan. Persediaan merupakan sumber daya yang penting bagi kelangsungan hidup perusahaan. Persediaan meliputi semua barang yang dimiliki perusahaan pada saat tertentu dengan tujuan untuk dijual atau diolah kembali dalam kegiatan operasi perusahaan dengan tujuan untuk menghasilkan laba (Riswan dan Restianti, 2016). 
Penelitan yang dilakukan untuk mengetahui faktor-faktor apa saja yang dapat mempengaruhi perusahaan dalam memilih metode penilaian persediaan. Penelitian yang dilakukan oleh Marwah (2012) menguji analisis faktor yang mempengaruhi pemilihan metode akuntansi persediaan pada perusahaan manufaktur yang terdaftar di BEI tahun 2007-2010. Hasil dari penelitian adalah Variabel ukuran perusahaan berpengaruh secara signifikan terhadap pemilihan metode akuntansi persediaan. Variabel leverage, likuiditas, dan laba sebelum pajak tidak berpengaruh terhadap pemilhan metode penilaian persediaan.

Penelitian yang dilakukan oleh Maharani (2014), penilitian ini menguji pengaruh ukuran perusahaan, margin laba kotor dan perputaran persediaan terhadap pemilihan metode akuntansi persediaan pada perusahaan manufaktur sektor industri barang konsumsi yang terdaftar di BEI tahun 2009-2013. Hasil dari penelitian adalah ukuran perusahaan, margin laba kotor, dan perputaran prsediaan tidak memberikan pengaruh signifikan terhadap pemilihan metode penilaian persediaan.

Penelitian yang dilakukan Riswan dan Restiani (2016), penelitian ini menguji Analisis faktor-faktor yang mempengaruhi pemilihan metode akuntansi persediaan pada perusahaan manufaktur di bursa efek indonesia tahun 2010-2014. Hasil dari penelitian ini adalah variabel ukuran perusahaan, kepemilikan manajerial, Financial leverage berpengaruh secara signifikan terhadap pemilihan metode akuntansi persediaan. Variabel rasio lancar tidak memberikan pengaruh terhadap pemilihan metode akuntansi persediaan.

\section{TINJAUAN PUSTAKA}

\section{Teori Akuntansi Positif}

Menurut teori akuntansi positif, prosedur akuntansi yang digunakan oleh perusahaan tidak harus sama dengan yang lainnnya, namun perusahaan diberi kebabasan untuk memilih salah satu alternatif prosedur yang tersedia untuk meminimumkan biaya kontrak dan memaksimalkan nilai perusahaan. Dengan adanya kebebasan itulah, maka menurut Scott (2000) manajer mempunyai kecenderungan melakukkan suatu tindakan yng menurut teori akuntansi positif dinamakan sebagai tindakan oportunis (oppoertunistic behaviior). Jadi, tindakan oporatunis adalah suatu tindakan yang dilakukkan oleh perusahaan dalam memilih kebijakan akuntansi yang menguntungkan dan memksimumkan kepuasan perusahaan tersebut. Terdapat tiga teori hipotesis akuntansi positif, yaitu :

1) Hipotesis Program Bonus (The Bonus Plans Hypothesis)

2) Hipotesis Perjanjian Hutang (The Debts Covennts Hypothesis) 


\section{3) Hipotesis Biaya Politik (The Politcal Cosst Hypothesis)}

Berdasarkan definisi, peneliti dapat melihat hubungan teori akuntansi positif (positive accounting theory) dengan penelitian ini. Seperti yang sudah dijelaskan, dalarm teori akuntansi positif (positive accounting theory) ada berbagai motivasi yang mendorong untuk mendapatkan laba semaksimum mungkin. Salah satu cara yng dapat ditempuh manager adalah dengan menyesuaikan antara metode akuntansi persediaan yang digunakkan dengan kondisi ekeonomi yang sedang terjadi sehingga dapat meningkatkan laba atau menurunkan laba, untuk mengurangi pajak yang harus dibayarkan. Ketika terjadi iniflasi, metode FIFO akan menghasilkan laba yang lebih besar dari pada menggunakan metode rata-rata. Sebaliknya, perusahaan yang menggunakkan metode rata-rata diuntungkan dalam hal pembayaran pajak karaena pajak yarng harus dibayarkan menjadi lebih kecil.

\section{Persediaan}

Menurut Pernyataaan Standar Akuntansi Keuangaan (PSAK)) No. 14 (revisi 2015) (dalam Tutuk, 2017) yang dimaksud dengan persediaan adalah aset:

1. Tersedia untuk dijual dalam kegiatan usaha normal,

2. Dalam proses produksi untuk penjualan tersebut, atau

3. Dalam bentuk bahan dan perlengkapan (supplies) untuk digunaakan dalam proses produksi atau pemberian jasa.

\section{Metode Penilaian Presediaan}

Beredasarkan PSAK No. 14 (2015)) terdapat dua macam metode akuntansi persediaan yang boleh diguanakan di Indonesia sekarang ini, yaitu metoede Firsts In Firsts Out (FIFO) dan metode rata-rata tertimbang atau metode weighteds averaege.

1. Metode FIFO(First In First Outs)

Menurut Keiso, et.al (2007), yang diterjemahkan oleh Salim (2007:418) "Metode FIFO (First In Frst Out) megasumsikan bahawa barang-barangyang diguanakan (dikeluarkan) sesuai urutan pembeliannya. Dengan kata lain, metode ini mengasumsikan bahwa barang pertama yang dibeli adalah barang pertama yang digunakan (dalam perusahaan manufaktur) atau dijual (dalam perusahaan dagang). Oleh karenanya, persediaan yang tersisa merupakan barang yang dibeli paling terakhir".

2. Metode Rata-Rata

Menurut Horisson, Horngren, Thomas, dan Suwardy (2013), yang diterjemahkan oleh Gina Gania (2012:366) metode rata-rata merupakan metode kalkulasi biaya persediaan yang 
didasarkan pada biaya rata-rata persediaan selama periode berjalan. Biaya rata-rata ditentukan dengan cara membagi harga pokok barang yang tersedia dengan jumlah unit yang tersedia.

\section{Pemilihan Metode Peniliaan Persediaan}

Pada penelitian ini pemilihan metode akuntansi persediaan mengacu pada PSAK No.14 (Revisi, 2015) yang menyatakan bahwa diberlakukannya dua metode akuntansi persediaan yaitu Firsts In Firsts Out (FIFO) dan rata-rata tertimbang (Weighted Average). Pada awal, PSAK 14 (1994) ada tiga metode yang diakui FIFO, LIFO dan metode ratarata. Namun pemiilihan metode akuntansi persediaan di Indonesia mengacu pada Pernyataan Standar Akuntansi Keuangan (PSAK) Nomor 14 (revisi 2015), yang menyatakan bahwa hanya metode FIFO (firsts in firste out) dan AVERAGE (weigthted average) yang dapat memilih dalam menentukan arus biaya persediaan. Hal ini sejalan dengan UndangUndang No.7 Tahun 1983 dan Undang-Undang No.10 tahun 1994 tentang perpajakan yang hanya memperbolehkan penggunaan metode AVERAGE (dalam Tutuk, 2017).

Sejak tahun 2009 PSAK Indonesia melarang metode LIFO yangg digunakan oleh perusahaan karena sedikit demi sedikit mulai mengadopsi IFRS (Internasional Financial Reporting Standards) yang dikeluarkan oleh Badan Standar Akuntansi Internationals yang bertujuan untuk mengharmoniskan standar akuntansi internasional. Undang-Undang Pajak Penghasilan No.36 Tahun 2008 yang juga hanya memperbolehkan perusahaan menggunakan metode FIFO dan rata-rata dan tidak mengunakan metode LIFO.

\section{Ukuran perusahaan}

Ukuran perusahaan merupakan cerminan total dari asset yang dimiliki perusahaan. Perusahaan sendiri dikategorikan menjadi dua jenis, yaitu perusahaan berskala kecil dan perusahaan berskala besar. Semakin besar ukuran perusahaan, berarti asset yang dimiliki perusahaan pun semakin besar dan dana yang dibutuhkan perusahaan untuk mempertahankan kegiatan operasionalnya pun semakin banyak. Semakin besar ukuran perusahaan akan mempengaruhi keputusan manajemen dalam memutuskan pendanaan apa yang akan dipergunakan oleh perusahaan supaya keputusan pendanaan dapat mengoptimalisasikan nilai perusahaan (Pratama dan Wiksuana, 2016)

\section{Likuiditas}

Likuiditas adalah kemampuan perusahaan memenuhi hutang jangka pendeknya dengan menggunakan aktiva lancar (Sangadah, 2014). 


\section{Leverage}

Leverage merupakan hubungan diantara hutang perusahaan pada modal maupun aset. Rasio ini juga dapat dipergunakan untuk melihat berapa besar perusahaan dibiayai oleh pihak luar dibanding dengan kemampuan perusahaan sendiri yang digambarkan dengan modal (Prasetyorini, 2013).

\section{Margin Laba Kotor}

Menurut Hery, (2017) dalam bukunya "Kajian Riset Akuntansi" margin laba kotor merupakan rasio yang dipergunakan untuk mengukur besar presentase laba kotor atas penjualan. Semakin tinggi margin laba kotor maka semakin tinggi pula laba kotor yang dihasilkan dari penjualan bersih. Hal ini dapat disebabkan karena tingginya harga jual dan/atau rendahnya harga pokok penjualan.

\section{Hipotesis Penelitian}

Mengacu pada kerangka pemikiran, tinjauan teoritis dan beberapa penilitian sebelumnya. Maka dapat dirumuskan hipotesis penelitian sebagai berilut:

H1 : Diduga ukuran perusahaan berpengaruh terhadap pemilihan metode penilaian persediaan pada perusahaan manufaktur yang terdapat di Bursa Efek Indonesia

H2 : Diduga likuiditas berpengaruh terhadap pemilihan metode penilaian persediaan pada perusahaan manufaktur yang terdapat di Bursa Efek Indonesia

H3 : Diduga leverage berpengaruh terhadap pemilihan metode penilaian persediaan pada perusahaan manufaktur yang terdapat di Bursa Efek Indonesia

H4 : Diduga margin laba kotor berpengaruh terhadap pemilihan metode penilaian persediaan pada perusahaan manufaktur yang terdapat di Bursa Efek Indonesia

\section{METODE PENELITIAN}

\section{Jenis dan Sumber Data}

Data yang diagunakan dalam penelitian ini adalah data sekunder. Data sekunder dalam penelitian ini berupa laporan keuangan perusahaan manufaktur makanan dan minuman yang terdaftar di Bursa Efek Indinesia pada tahun 2016-2018 untuk analisis data. Laporan keuangan perusahaan yang digunakan sebagai data dapat didownload di website www.idx.co.id. 


\section{Populasi dan Sampel}

Populasi dalam penlitian adalah perusahaaan manfaktur makanan dan minuman yang terdaftar di Bursa Efek Indonesia dengan periode pengamatan tahun 2016-2018. Sampel yang digunakan dalam penelitan ini menggunakan metode purposive sampling.

Menurut (Sugiyono, 2016:85). Pureposive sampling adalah tekhnik penentuan sample dengan pertimbangan tertentu. Pertimbangan yang dipergunakan dalam pemilhan sampel adalah :

1. Perusahaan manufaktur makanan dan minuman yang terdaftar di Bursa Efek Indonesia dan mempublikasikan laporan keuangan perusahaan selama tiga tahun (20162018).

2. Perusahaan tersebut hanya menggunakan metode penilaian persediaan saja, baik metode FIFO atau metode rata-rata untuk semua persediaan.

3. Perusahaan tersebut menggunakan metode penilaian persediaan secara konsisten selama tiga tahun (2016-2018).

Tabel 1. Proses penyaringan Populasi Menjadi Sampel

\begin{tabular}{|c|l|c|}
\hline No. & \multicolumn{1}{|c|}{ Keterangan } & $\begin{array}{c}\text { Jumlah } \\
\text { Perusahaan }\end{array}$ \\
\hline 1. & Total persahaan yang menjadi populasi & 23 \\
\hline 2. & $\begin{array}{l}\text { Perusahaan yang tidak mepublikasikan laporan } \\
\text { keuangan pada periode penelitian }\end{array}$ & 11 \\
\hline 3. & $\begin{array}{l}\text { Perusahaa yang tidak konsisten dalam menerapkan 1 } \\
\text { (satu) metode penilaian persediaan }\end{array}$ & 0 \\
\hline 4. & Perusahaan yang memenuhi kriteria menjadi sampel & 12 \\
\hline & $\begin{array}{l}\text { Jumlah sampel akhir } \\
\text { Tahun pengamatan } \\
\text { Jumlah pengamatan }\end{array}$ & $\mathbf{1 2}$ \\
$\mathbf{3}$
\end{tabular}

Sumber : data olahan, 2019

\section{OPERASIONAL VARIABEL}

\section{Ukuran perusahaan}

Menurut Sujianto (2001:19) (dalam Sendi Betha Oktavianto, Maslichah dan Afifudin, 2019) ukuran perusahaan merupakan gambaran besar kecilnya perusahaan yang ditentukan berdarkan ukuran nominal. Ukuran perusahaaan dihitung dari total asset yang dimliki setiap perusahaan sampel dari tahun 2016 sampai 2018.

$$
\text { Size }=\operatorname{Ln}(\text { Total Aktiva })
$$




\section{Likuiditas}

Likuiditas merupakan kemampuan perusahaan untuk memenuhi kewajiban jangka pendeknya (Sangadah, 2014). Likuiditas dalam penelitian ini diukur dengan current ratio yaitu dengan menggunakan perbandingan antara aktiva lancar degan hutang lancar.

$$
\text { Likuiditas }=\frac{\text { Aset Lancar }}{\text { Hutang Lancar }}
$$

\section{Leverage}

Leverage adalah kemampuan perusahaan untuk menggunakan aktiva atau dana yang mempunyai beban tetap (fixeds cost assets or fund) untuk memperbesar tingkat penghasilan (returns) bagi pemilik perusahaan (Setiyanto, 2012). Leverage membayar hutang jangka panjang dengan kekayaan yang dimilikinya.

$$
\text { Leverage }=\frac{\text { Total Hutang Jangka Panjang }}{\text { Total Asset }}
$$

\section{Margin laba kotor}

Margin laba kotor merupakan rasio yang dipergunakan untuk mengukur besar presentase laba kotor atas penjualaan (Hery, 2017). Margin laba kotor dihitung dengan cara membagi laba kotor dengan penjualan bersih.

$$
\text { Margin Laba Kotor }=\frac{\text { Laba Kotor }}{\text { Penjualan Bersih }}
$$

\section{Teknik Analisis Data}

Hipotesisi dalam penlitian ini diuji dengan menggunakan penguji regresi logistik. Regresi logistic sebetulnya sama dengan regeresi berganda hanya saja dengan menggunakan variable dummy atau variabel kualitatif, variable dalam model diberi nilai 1 dan 0 untuk masing-masing kategori. Peneliti memberikan nilai 0 untuk FIFO dan 1 untuk averages $(\mathrm{FIFO}=0$, Average $=1)$ Model yang digunakan:

$$
L n=\frac{P}{1-P}=\alpha+\beta_{1} U P+\beta_{2} L k+\beta_{3} L e v+\beta_{4} M L K+e
$$

Dimana :

P : Pemilihan metode peniliaian presediaan

a : Konstanta

UP : Ukuran Perusahaan 
Lk : Likuiditas

Lev : Leverage

MLK : Margin Laba Kotor

$\beta_{1} \ldots \beta_{4}:$ Koefisien regresi

e $\quad$ : Error

Pengujian hipotesis pada regresi logistik dilakukan dengan menggunakan tingkat signifikan $(\alpha) 5 \%$. Kriteria penerimaan atau penolakan hipotesis akan didasarkan nilai pvalue. Kuputusannya berdasarkan probabilitas sebagai berikut :

1) Apabila p-value $>0,05$ maka hipotesis ditolak.

2) Apabila p-value $<0,05$ maka hipotesis diterima.

\section{HASIL DAN PEMBAHASAN}

\section{Analisis Statistik Deskriptif}

Analisis statistik deskriptif adalah untuk memberikan gambaran atau deskripsi suatu data yang dilihat dari nilai rata-rata (mean), standar deviasi, maksimum, minimum (Ghozali, 2018). Hasil statistik deskriptif dalam penelitian ini sebagai berikut :

Tabel 2. Hasil analisis Deskriptif

Descriptive Statistics

\begin{tabular}{|l|l|l|l|l|l|}
\hline & & & Maximu & & \\
\cline { 4 - 6 } & $\mathrm{N}$ & Minimum & Mean & Std. Deviation \\
\hline Ukuran Perusahaan & 36 & 12,578 & 20,363 & 15,60549 & 2,085676 \\
Likuiditas & 36 &, 680 & 8,638 & 2,26368 & 1,862919 \\
Leverage & 36 &, 024 &, 396 &, 14548 &, 113888 \\
Rasio Margin Laba Kotor & 36 &, 011 &, 525 &, 15025 &, 154543 \\
Persediaan & 36 & 0 & 1 &, 92 &, 280 \\
Valid N (listwise) & 36 & & & & \\
\hline
\end{tabular}

Sumber: Outpute SPSS Versi 22

\section{Uji Asumsi Klasik}

Uji Multikolonieritas

Tabel 3. Hasil Uji Multikoliearitas

Coefficients $^{\mathrm{a}}$

\begin{tabular}{|ll|r|r|}
\hline \multirow{2}{*}{ Model } & \multicolumn{2}{|c|}{ Collinearity Statistics } \\
\cline { 2 - 4 } & Tolerance & VIF \\
\hline $1 \quad$ Constant) & & \\
& Ukuran Perusahaan &, 935 & 1,069 \\
& Likuiditas &, 829 & 1,207 \\
& Leverage &, 873 & 1,146 \\
& Rasio Margin Laba Kotor &, 869 & 1,150 \\
\hline
\end{tabular}

Sumber : Outpute SPSS Versi 22 
Pada tabel coeffisien terlihat untuk variabel ukuran perusahaan, likuiditas, leverage dan margin laba kotor diketahui nilai tolerance secara berturut-turut sebesar 0,$935 ; 0,829 ; 0,873$; 0,869. Sedangkan nilai VIF yaitu sebesar 1,$069 ; 1,207 ; 1,146 ; 1,150$. Berdasarkan tabel diatas, diketahui bahwa seluruh variabel independen memiliki nilai tolereance lebih besar dari 0,1 dan VIF seluruh variabel kurang dari 10 sehingga dapat disimpulkan bahwa variabel independen ukuran perusahaan, likuiditas, leverage dan margina laba kotor tidak mempunyai masalah dengan multikolinieritas.

\section{Uji Autokorelasi}

Tabel 4. Hasil Uji Autokorolasi

\begin{tabular}{|l|r|r|r|r|r|}
\hline Model & \multicolumn{1}{|c|}{ R } & R Square & $\begin{array}{c}\text { Adjusted R } \\
\text { Square }\end{array}$ & $\begin{array}{c}\text { Std. Error of the } \\
\text { Estimate }\end{array}$ & $\begin{array}{l}\text { Durbin- } \\
\text { Watson }\end{array}$ \\
\hline 1 &, $558^{\mathrm{a}}$ &, 311 &, 222 &, 422 & 1,145 \\
\hline
\end{tabular}

a. Predictors: (Constant), Rasio Margin Laba Kotor, Ukuran Prusahaan,

Leverage, Likuiditas

b. Dependent Variable: Persediaan

Sumber : Output SPSS Versi 22

Tabel 4 menunjukkan nilai DW sebesar 1,145 pada taraf signifikan 0,05 dengan variabel bebas $\mathrm{k}=4$ dan $\mathrm{n}=36$, maka di tabel Durbin Watson akan didapat nilai sebagai berikut:

Tabel 5. Durbin Watson Test

\begin{tabular}{|l|l|l|}
\hline & $\mathrm{k}=4$ & \\
\hline $\mathrm{N}$ & $\mathrm{dL}$ & $\mathrm{dU}$ \\
\hline 10 & 0,3760 & 2,4137 \\
\hline.. &.. &.. \\
\hline 36 & 1,2358 & 1,7245 \\
\hline
\end{tabular}

Sumber : Output SPSS Versi 22

Uji autokorelasi menggunakan pengujian Durbin-Watson. Berdasarkan hasil perhitungan dengan bantuan program SPSS, menunjukkan hasil sebesar 1,145 dengan $\mathrm{n}=36$ dan $\mathrm{k}=4$ maka dapat diketahui DW terletak antara dU dan $(4-\mathrm{dU})=1,2358<1,949<1,7245$ maka dapat disimpulkan bahwa H0 tidak bisa ditolak yang artinya tidak ada autokorelasi atau tidak terdapat autokorelasi positif maupun negatif pada data yang diuji. 


\section{Uji Heteroskedastisitas}

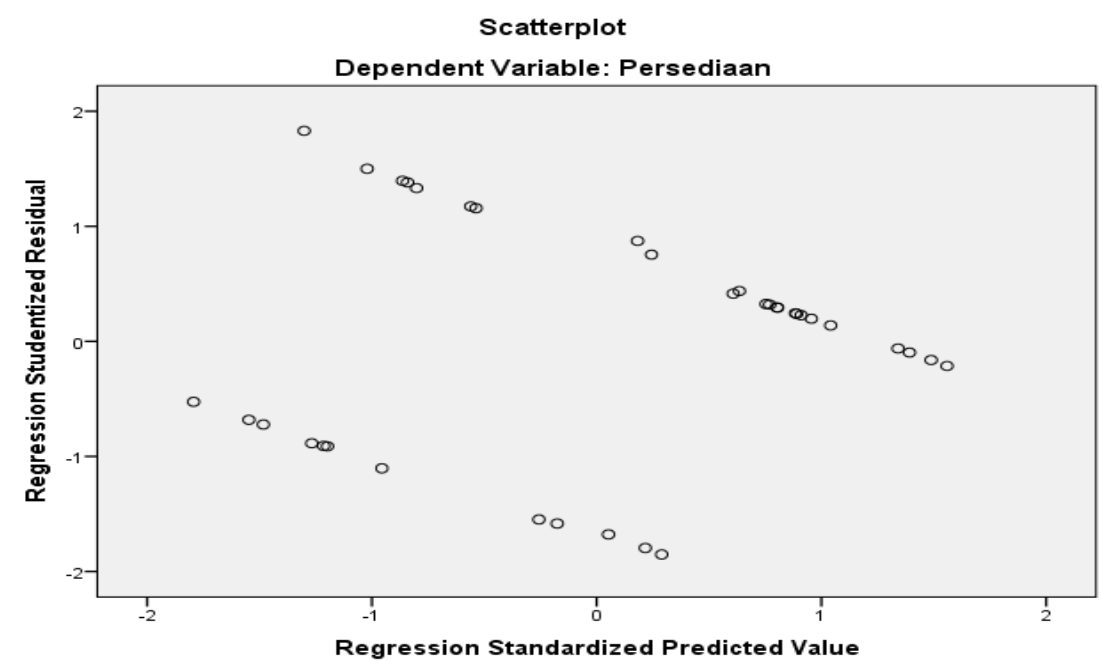

Gambar 1. Grafik Scatterplote

Dari grafik scatterplote pada gambar 1, menunjukkan bahwa pola yang terbentuk berupa titik-titik yang tidak beraturan yang menyebar diatas dan dibawah angka nol (0) pada sumbu Y, sehingga dapat disimpulkan bahwa model regresi tidak terjadi heteroskedastisitas.

\section{Analisis Regresi Logistik}

Menilai Keseluruhan Model Fit (Overall Model Fit)

Tabel 6. Perhitungan Block 0 Overall Model Fit

\begin{tabular}{|ll|r|r|}
\multicolumn{3}{|c}{ Iteration History $\mathbf{a , b , c}$} \\
\hline \multirow{3}{*}{ Iteration } & & -2 Log & Coefficients \\
\cline { 4 - 4 } & & likelihood & \multicolumn{1}{c|}{ Constant } \\
\hline Step 0 & 1 & 45,835 &, 667 \\
& 2 & 45,829 &, 693 \\
& 3 & 45,829 &, 693 \\
\hline
\end{tabular}

a. Constant is included in the model.

b. Initial -2Log Likelihood: 45,829

c. Estimation terminatedt at iteration number 3 becaus parametere estimates changed by less than ,001.

Sumber: Outpus SPSS versi 22

\section{Tabel 7. Perhitungan Block 1 Overall Model Fit}

\begin{tabular}{|c|c|c|c|c|c|c|}
\hline \multicolumn{7}{|c|}{ Iteration History $^{\mathbf{a}, \mathbf{b}, \mathbf{c}, \mathbf{d}}$} \\
\hline \multirow[b]{2}{*}{ Iteration } & \multirow{2}{*}{$\begin{array}{c}-2 \log \\
\text { likelihood }\end{array}$} & \multicolumn{5}{|c|}{ Coefficients } \\
\hline & & Constant & Size & Liq & Lev & GPMR \\
\hline Step 11 & 34,528 & 6,865 &,- 389 & ,205 & ,964 & $-4,969$ \\
\hline 2 & 33,354 & 9,866 &,- 541 & ,201 & ,653 & $-6,813$ \\
\hline
\end{tabular}




\begin{tabular}{|c|r|r|r|r|r|r|}
\hline \multirow{2}{*}{ Iteration } & \multicolumn{1}{|c|}{-2 Log } & \multicolumn{5}{|c|}{ Coefficients } \\
\cline { 3 - 7 } & likelihood & Constant & \multicolumn{1}{|c|}{ Size } & \multicolumn{1}{c|}{ Liq } & \multicolumn{1}{c|}{ Lev } & GPMR \\
\cline { 2 - 7 } 3 & 33,261 & 11,057 &,- 600 &, 186 &, 409 & $-7,485$ \\
4 & 33,260 & 11,206 &,- 607 &, 184 &, 374 & $-7,569$ \\
5 & 33,260 & 11,209 &,- 607 &, 184 &, 373 & $-7,570$ \\
6 & 33,260 & 11,209 &,- 607 &, 184 &, 373 & $-7,570$ \\
\hline
\end{tabular}

a. Method: Enter

b. Constant is included in the model.

c. Initial -2Log Likelihood: 45,829

d. Estimation terminatedt at iteration number 6 becaus parametere estimates changd by less than, 001 .

Sumber: Outpus SPSS versi 22

Penilaian keseluruhan model dilakukan dengan cara membandingkan nila antara -2 Log Likehood (-2LL) pada awal (Block Number $=0$ ), yakni model hanya memasukkan konstanta dengan nila -2 Log Likehood (-2LL) pada akhir (Block Number = 1), yakni model memasukkan konstanta dan variabel bebas. Berdasarkan tabel 6 dan tabel 7 dapat dijelaskan bahwa nilai -2LL awal adalah sebesar 45,829 dan nilai -2LL akhir sebesar 33,260 sehingga mengalami penurunan. Penurunan nilai -2LL ini berarti model yang dihipotesiskan fit dengan data atau dapat dikatakan model regresi baik.

\section{Uji Kelayakan Model Regresi}

\section{Tabel 8. Penilaian Kelayakan Model Regresi}

Hosmer andLemeshow Test

\begin{tabular}{|l|r|r|r|}
\hline Step & Chi-square & df & \multicolumn{1}{c|}{ Sig. } \\
\hline 1 & 9,313 & & 7 \\
\hline
\end{tabular}

Sumber: Outpus SPSS versi 22

Berdasarkan pengujian nilai statistik Hosmer dan Lemeshow Goodness of Fit adalah sebesar 9,313 dengan probabilitas signifikansi sebesar 0,231 nilai ini jauh 0,05 dengan demkian dapat disimpulkan bahwa model tersebut diterima yang artinya tidak terdapat perbedaan dengan data sehingga model dapat dikatakan fit model mampu memprediksi nila observasinya atau dapat dikatakan model bisa diterima karena sesuai degan data observasinya. 


\section{Uji Koefisien Determinasi(Nagelkerke's $R$ Square)}

Tabel 9. Perhitungan Nagelkerke's R Square

\section{Model Summary}

\begin{tabular}{|l|c|c|c|}
\hline Step & $\begin{array}{c}-2 \text { Log } \\
\text { likelihood }\end{array}$ & $\begin{array}{c}\text { Cox } \\
\text { \& Snell R } \\
\text { Square }\end{array}$ & $\begin{array}{c}\text { Nagelkerke R } \\
\text { Square }\end{array}$ \\
\hline 1 & $33,260^{\mathrm{a}}$ &, 295 &, 409 \\
\hline
\end{tabular}

a. Estimation terminatd at iteration number 6 becaus parameterestimates changed by less than ,001.

Sumber: Outpus SPSS versi 22

Tabel 9 menunjukkan nilai Nagelkerke RSquare. Dilihat dari hasil output pengolahan data nilai Nagelkerke RSquare adalah sebesar 0,409 yang berarti variabilitas dependent yang dapat dijelaskan oleh variable independent sebesar $40,9 \%$ sisanya sebesar $59,1 \%$ $(100 \%-40,9 \%)$ dijelaskan variabilitas variabel-variabel lain di luar model penelitian.

\section{Model Regresi Logistik yang Terbentuk dan Pengujian Hipotesis}

Model regresi logistic dapat dibentuk dengan melihat Variables inThe Equations pada tabel 10 di bawah ini:

Tabel 10. Perhitungan Variables in The Equation

Variables in the Equation

\begin{tabular}{|ll|r|r|r|r|r|r|}
\hline & \multicolumn{1}{|c|}{ B } & \multicolumn{1}{|c|}{ S.E. } & \multicolumn{1}{|c|}{ Wald } & \multicolumn{1}{c|}{ df } & \multicolumn{1}{c|}{ Sig. } & \multicolumn{1}{|c|}{$\operatorname{Exp(B)}$} \\
\hline${\text { Step } 1^{\text {a }}}$ & Size &,- 607 &, 267 & 5,182 & 1 &, 023 &, 545 \\
& Liq &, 184 &, 243 &, 573 & 1 &, 449 & 1,202 \\
& Lev &, 373 & 3,998 &, 009 & 1 &, 926 & 1,453 \\
& GPMR & $-7,570$ & 3,430 & 4,872 & 1 &, 027 &, 001 \\
& Constant & 11,209 & 5,021 & 4,984 & 1 &, 026 & 73760,178 \\
\hline
\end{tabular}

a. Variable(s) entered on step 1: Size, Liq, Lev, GPMR.

Sumber: Output SPSS versi 22

Berdasarkan model penelitian yang digunakan, maka persamaan regresi yang didapat adalah sebagai berikut :

$$
Y=-356,693+28,047 U P+0,925 \text { Lk - 91,467Lev - 46,640MLK }+e
$$

Untuk menginterpretasikan hasil analisis tersebut dapat diterangkan sebagai berikut:

a. Dari hasil persamaan diperoleh nilai konstanta (a) sebesar 11,209 yang artinya jika tidak dipengaruhi oleh ukuran perusahaan, likuiditas, leverage dan margin laba kotor maka besarnya metode penilaian persediaan sebesar 11,209. 
b. Koefisien regresi ukuran perusahaan sebesar -0,607. Artinya jika variabel ukuran perusahaan naik satu satuan, sementara variabel independen lainnya tetap, maka akan menyebabkan penurunan sebesar 0,607 pada metode penilaian persediaan.

c. Koefisien regresi likuiditas sebesar 0,184. Artinya jika variabel likuiditas naik satu satuan, sementara variabel independen lainnya tetap, maka akan menyebabkan kenaikan sebesar 0,184 pada metode penilaian persediaan.

d. Koefisien regresi leverage sebesar 0,373. Artinya jika variabel leverage naik satu satuan, sementara variabel independen lainnya tetap, maka akan menyebabkan kenaikan sebesar 0,373 pada metode penilaian persediaan.

e. Koefisien regresi margin laba kotor sebesar -7,570. Artinya jika variabel margin laba kotor naik satu satuan, sementara variabel independen lainnya tetap, maka akan menyebabkan penurunan sebesar 7,570 pada metode penilaian persediaan.

\section{HASIL DAN PEMBAHASAN}

\section{Pengaruh Ukuran Perusahaan Terhadap Pemilihan Metode Penilaian Persediaan}

Ukuran perusahaan dalam penelitian ini diukur dari total asset perusahaan tiap tahun. Hasil pengujian untuk ukuran perusahaan diperoleh nilai signifikansi sebesar 0,023 , maka jika dibandingkan dengan tingkat signifikasi 5\%, diketahui bahwa tingkat signifikan 0,023 lebih kecil dari 0,05 . Hal ini membktikan bahwa ukuran perusahaan berpengaruh terhadap pemilihan metode penilaian persediaan.

Penelitian ini menunjukkan bahwa ukuran perusahaan berpengaruh terhadap pemilihan metode penilaian persediaan karena perusahaan yang digunakan dalam penelitian ini adalah perusahaan manfaktur makanan dan minuman yang terdaftar di BEI, dengan kata lain perusahaan yang dipergunakan dalam penelitian ini adalah perusahaan besar. Perusahaan besar memiliki kecenderungan untuk menggunakan metode rata-rata agar laba perusahaan terlihat tidak setinggi jika menggunakan metode FIFO, sehingga pajak yang dibayarkan juga rendah.

Kenyataan yang dihasilkan pada penelitian ini adalah perusahaan besar cenderung memilih menggunakan metode persediaan average dibandingkan metode FIFO. Hal ini sesuai dengan teori yang ada dimana perusahaan besar cenderung memilih metode average yang dapat menurunkan laba, sedangkan pada perusahaan kecil cenderung memilih metode FIFO agar dapat meningkatkan laba, sehingga akan memberikan gambaran kinerja yang bagus. 
Dengan demikian kemungkinan mendapatkan dana dari bank atau lembaga keungan lainnya semakin besar.

Hasil penelitian konsisten dengan penelitian yang dilakukan oleh Marwah (2012), Setiyanto (2012), Sangeroki (2013), Riswan dkk (2016), dan Siregar (2017) yang meyatakan bahwa ukuran perusahaan berpengaruh terhadap pemilihan metode penilaian persediaan.

\section{Pengaruh Likuiditas Terhadap Pemlihan Metode Penilaian Persediaan}

Likuiditas dalam penelitian ini diukur menggunakan rasio lancar perusahaan tiap tahun. Hasil pengujian untuk likuiditas diperoleh nilai signifikansi sebesar 0,449, maka jika dibandingkan dengan tingkat signifikasi 5\%, diketahui bahwa tingkat signifikan 0,449 lebih besar dari 0,05. Hal ini membuktkan bahwa likuiditas tidak berpengaruh scara signifikan terhadap pemilihan metode penilaian persediaan.

Perusahaan dengan tingkat laba yang tinggi dinilai akan mendapat perhatian luas dari kalangan konsumen dan media yang nantinya juga akan menarik perhatian pemerintah dan regulator sehingga menyebabkan terjadinya biaya politis. Berdasarkan teori diatas dapat diketahui bahwa perusahaan yang memiliki tingkat likuiditas yang tinggi cenderung akan memilih metode rata-rata karena metode ini menghasilkan laba yang rendah dibandingkan metode FIFO sehingga dapat terhindar dari biaya politis (Marwah, 2012).

Hasil penelitian konsisten dengan Sarifudin (2010), Marwah (2012), dan Sangadah (2014) sesuai rasio lancar sebagai ukuran likuiditas perusahaan tidak berhasil dibuktikan mempunyai pengaruh yang signifikan terhadap pemilihan metode penilaian persediaan. Meskipun secara konsep likuiditas dapat menjadi factor yang mepengaruhi pemilihan metode penilaian persediaaan, namun dalam penelitian ini tidak menyatakan demikian. Peneliti menduga hal ini disebabkan perusahaan selalu berusaha meningkatkan kesejahteraannya dengan memilih metode yang dapat meminimalkan pembayaran pajak. Dengan demikian, perusahaan akan memilih metode persediaan tanpa memperhatikan besarnya hutang lancar pada perusahaan tersebut.

\section{Pengaruh Leverage Terhadap Pemilihan Metode Penilaian Persediaan}

Leverage merupakan rasio yang digunakan untuk mengukur sejauh mana aktiva pada perusahan dibiayain oleh hutang (Kasmir, 2012: 136). Konsep leverage yaitu dimana semakin tinggi rasio financial leverage perusahaan, maka preusahaan cenderung utuk meningkatkan laba dengan memilih mengunakan penilaian persediaan FIFO. 
Hasil pengujian untuk leverage diperoleh nilai signifikansi sebesar 0,926, maka jika diperbandingkan dengan tingkat signifikan 5\%, diketahui bahwa tingkat signifikan 0,926 lebih besar dari 0,05 . Hal ini membuktikan bahwa leverage tidak berpengaruh secara signifikan terhadap pemilihan metode penilaian persediaan. Hasil penelitian konsisten dengan Setiyanto (2012), Hutahaean (2014) dan Ayem (2018) menunjukkan bahwa leverage tidak berpegaruh terhada pemilihan metode penilaian persediaan

Variabel leverage diukur dengan membandingkan total utang jangka panjang terhadap total aktiva namun tetap tidak dapat membuktikan bahwa leverage berpengaruh terhadap pemilihan metode akuntansi persediaan. Hal ini bahwa perusahaan tidak memperhatikan besar kecilnya hutang jangka panjang dalam memilih metode penilaian persediaan.

\section{Pengaruh Margin Laba Kotor Terhadap Pemilihanm Metode Penilaian Persediaan}

Margin laba kotor merupakan rasio yang dipergunakan untuk mengukur besarnyapersentase laba kotor atas pejualan bersih. Rasio ini dihitung dngan membagi laba kotor terhadap penjualan bersih. Laba kotor sendiri dihitung sebagai hasil pengurangan antara penjualan bersih dengan harga pokok penjualan, yang dimaksudkan dengan penjualan bersih disini adalah penjualan (tunai maupun kredit) dikurangi retur dan penyesuaian harga jual serta potongan penjualan (Hery, 2015: 231-232).

Penelitian variabel margin laba kotor dengan mengunakan regresi logistic diperoleh signifikasi sebesar 0,027, maka jika dibandingkan dengan tingka signifikai 5\%, diketahui bahwa tingkat signifikasi 0,027 lebih kecil dari signifikasi 0,05, sehingga variabel margin laba kotor mempengaruhi pemilihan mertode penilaian pesediaan dalam peneltian. Hasil penelitian konsisten dengan penelitian yang dilakukan oleh Sangeroki (2013), Sangadah (2014), Mahardika (2017), Oktavianto dkk (2019) dan Kadim dkk (2019) yang menyatakan bahwa margin laba kotor bepengaruh terhadap pemilihan metode penilaian persediaan.

Hasil penelitian mengindikasikan bahwa semakin meningkatnya margin laba kotor perusahaan memperlihatkan semakin baiknya keadaan operasi pada perusahaan, disebabkan karena harga pokok penjualan yang relatife lebih rendah dibandingkan dengan penjualan. Sehingga dengan tingginya margin laba kotor yang dihasilkan oleh perusahaan akan berdampak pada kinerja manajemen yang dianggap baik di mata investor dan kreditor. Dengan tingginya margin laba kotor perusahaan maka akan menambah kemudahan perusahaan untuk mendapatkan pendanaan dari pihak kreditor. Sehingga tingginya margin laba kotor yang dihasilkan dari operasional perusahaan akan mempengaruhi kebijakan manajemen untuk 
mempertahankan metode persediaan tahun berikutnya dengan menghasilkan laba kotor yang besar dengan menggunakan metode persediaan FIFO. Begitu pula sebaliknya, rendahnya margin laba kotor perusahaan menunjukkan bahwa tingginya harga pokok penjualan perusahaan yang dihasilkan sehingga akan mendorong perusahaan kedepannya unntuk memperkecil harga pokok penjualannya.

\section{KESIMPULAN DAN SARAN}

\section{Kesimpulan}

Berdasarkan hasil penelitian yang telah dilakukan dan pembahasan bab-bab sebelumnya maka diambil beberapa kesimpulan sebagai berikut:

1) Hasil pengujian menunjukkan bahwa variabel ukuran perusahaan berpengaruh terhadap pemilihan metode penilaian persediaan.

2) Hasil pengujian menunjukan bahwa variabel likuiditas tidak berpengaruh terhadap pemlihan metode penilaian persediaan.

3) Hasil pengujian menunjukkan bahwa variabel leverage tidak berpengaruh terhadap pemilihan metode penilain persediaan.

4) Hasil pengujian menunjukkan bahwa variabel margin laba kotor berpengaruh terhadap pemlihan metode penilaian persediaan.

\section{Saran}

Berdasarkan kesimpulan, maka saran yang dapat dikemukakan dalam penelitian sebagai berikut:

1) Dalam hal pemilihan metode persediaan, hendaknya manager memilih metode yang tepat bagi kondisi perusahaan dengan memperhatikan faktor-faktor yang mempengaruhi pemilihan metode persediaan, namun tidak bertentangan dengan peraturan yaitu UU no 36 tahun 2008 khususnya pasal 10 dan PSAK 14 (Revisi 2008). Sehingga tetap akan memberikan keuntungan bagi perusahaan dan meningkatkan nilai perusahaan baik dari segi perusahaan itu sendiri maupun dari segi peraturan tentang penerapan metode persediaan.

2) Bagi penelitian selanjutnya, sebaiknya penelitian dilakukan lebih dari tiga tahun, sehingga data yang terkumpul dapat menunjukkan hasil yang lebih valid dan tidak bias.

3) Banyak factor yang mempengaruhi pemilihan metode akuntansi persediaan. Untuk peneliti selanjutnya disarankan untuk menambah variabel lainnya. 


\section{DAFTAR PUSTAKA}

Amin, M. A. N. (2020). Apakah Stock Split Memberikan Keuntungan Tidak Normal?. Permana : Jurnal Perpajakan, Manajemen, Dan Akuntansi, 12(1), 9-17. https://doi.org/10.24905/permana.v12i1.90

Ayem, S., Pratama, A., (2018). Pengaruh Ukuran Perusahaan, Variabiliatas Persediaan, Kepremilikan Manajerial, Finanicial Leverage Dan Laba Sebelum Pajak Terhadap Pemilihan Metode Akuntansi Persediaan (Studi Empris Pada Perusahaan Sub Sektor Farmasi Yang Terdaftar Di BEI Periode 2012-2016). Yogyakarta: Universitas Sarjanawiyata Tamansiswa Yogyakarta.

Baridwan, Z. (2008). Intermediate Accounting. Edisi 8. Yogyakarta. Universitas Gadjah Mada.

Ghozali, I., (2018). ApIlikasi Analisis Multivariated Dengan Progrm IBM SPSS. Edisi 9. Semarang. Badan Penerbit Universitas Diponegoro.

Hery. (2017). Kajian Riset Akuntansi. Jakarta : PT. Gasindo

Horngren., H., dkk. (2011). Akuntansi Keuangan International Financial Reporting Standards. Jilid 1. Jakarta : Erlangga.

Kieso, D. E. dkk. (2007). Akuntansi Intermediate. Jilid 1. Jakarta : Erlangga.

Maharani, R. (2014). Pengaruh Ukuran Preusahaan, Margin Laba Kotor Dan Perputaran Persediaa Pada Perushaan Manfaktur Sektor Industri Barang Konsumsi Yang Terdaftar Di Bursa Efek Indonesia Tahun 2009-2013. Tanjungpinang : Universitas Maritim Raja Ali Haji.

Mahardika, R., dkk. (2015). Analisis Factor-Factor yang Berpengaru terhadap Pemilhan Metode Akuntansi Persediaan (Studi pada Perusahaan Manfaktur yang Terdftar di BursaEfek Indonesia). Jurnal Akuntansi dan Pendidikan, Vol.4 No.2, IKIP PGRI Madiun.

Marwah, S. (2012). Analisis Factor-Factor Yang Mempengarhi Pemilihan Metode Penilaia Persediaan Pada Perusahaan Manufktur Yang Terdaftar Di BEI Tahun20072010. Semarang : Universitas Diponegoro.

Pratama, A., Bagus W. (2016). Pengaru Ukuran Perusahaan Dan Leverage Terhadap Nila Perusahaan Dengan Profitabilaitas Sebagai Variabble Mediasi. E-Jurnal Manajement Unud, Vol. 5, No. 2, 2016: 1338-1367. Bali : auaniversitas Udayana.

Riswan dan Restianti. (2016). Analisis Factor-Faktor Yang Mempengruhi Pemiliahan Metode Penilaia Presediaan Pada Prrusahaan Dagang Yang Terdaftar Di Bursa Efek IndonesiaPeriode 2010-2014. Lampung : Universitas Bandar Lampung.

Riyanto, B. (2001). Dasar-Dasar Pembelajaran Perusahaan. Yogyakarta. BPFE UGM.

Sangadah, S. (2014). Analisis Pemilihan Metode Akuntansi Persediaan Pada Perusahaa Manufakture. Semarang : Universitas Negeri Semarang.

Sangeroki, S. (2013). Ukuran Prrusahaan dan Margin Laba Kotor terhadap Pemilihan Metde Penilaian Persediaan di Perusahaan Manufakture. Jurnal EMBA 1185 
Voume 1 Nomor 3 September 2013, Hal. 1185-1192. Manado: Universitas Sam Ratulangi.

Santoso, I. (2007). Akuntansi Keuangan Menengah. PT Refika Aditama. Bandung.

Scott dan William. (2000). Financials Acconting Teory. Prentice Hall INC, A Simon \& Schuster Company, Upper Saddle River, New Jersey, USA.

Setijaningasih, H. T. dan Cecillia D. P. (2009). Pengaruh Bebrrapa Variable Terhadap Pemilihan Metode Penilain Persediaan Pada Perusahaan Manufktur. Vol. 10, No. 1, Jurnal The Winners, Jakarta Barat.

Setiyanto, K. B. (2012). Analisis Faktor-Factor Yang Berpngaruh Terhadap Pemilihan Metode Akuntansi Prrsediaan (Study Kasus Pada Perusahaan Manufactur Yang Terdaftara Di BEI Tahun2008-2010). Semarang. Universitas Diponegoro.

Sugiyono. (2016). Metode Penelitian Kuantitatife, Kualitatife, Dan R\&D. Bandung : Alfabet Bandung.

Syamsuddin, L. (2001). Manajemen Keuangan Perusahaan (Konsep AplikasiDalam Preencanaan, Prngawasan, Dan Pengambilan Keputusan). Jakarta : PT. Raja Grafindo Persada.

Tjahjono, A. dan Vica N. C. (2015). “Analisis Factor-Faktor Yang Berpengaru Terhadap Pemiliihan Metode Akuntansi Prrsediaan Pada Perushan Sub Sektore Perdagangan Besar Barang Produksi Dan Sub Sector Perdagangan Eaceran Yang TerdaftarDi Bursa Efek Indonesia (BEI) Tahun 2010-2013”. Vol. 23, No. 2, Jurnal Kajian Bisnis STIE Widya Wiwaha Yogyakarta.

Wats, R. L., Zimmerman J. D. (1990). Positive Accounting Theory : A Ten Years Perspektive. The Accounting Review 65 (January). Hal 131-156. 